\title{
Characterization of a Second Bovine Rotavirus Serotype
}

\author{
By \\ H. Brïssow ${ }^{1}$, S. Marc-Martin ${ }^{1}$, W. EichHorn ${ }^{2}$, \\ J. Sidoti ${ }^{1}$, and V. FRYDER ${ }^{1}$ \\ 1 Nestlé Research Department, Nestec Ltd., Vevey, Switzerland \\ 2 Institute of Medical Microbiology, Infectious and Epidemic Diseases, \\ Veterinary Faculty, University of Munich, Federal Republic of Germany \\ With 6 Figures \\ Accepted October 13, 1986
}

\begin{abstract}
Summary
Bovine rotavirus (BRV) V 1005 was characterized by two-way crossneutralization tests as a second serotype of BRV. Virions and inner shell particles of $65 \mathrm{~nm}$ and $55 \mathrm{~nm}$ diameter respectively, and empty capsids of $65 \mathrm{~nm}$ and $55 \mathrm{~nm}$ diameter were separated by density gradient centrifugation. Three polypeptides of molecular weight $60,000,36,000$ and 28,000 (minor protein) could be identified in the outer shell of virions and in the larger empty capsids. Inner shell particles contained three polypeptides of molecular weight $105,000,83,000$ and 43,000 . Both sizes of empty capsids showed two polypeptides of molecular weight 75,000 and 55,000 not found in virions. Pulse-labelling of infected cells revealed eight major and three minor intracellular viral polypeptides. Viral polypeptide synthesis started at about 6 hours p.i. and correlated in time with double-stranded RNA synthesis. As soon as viral polypeptide synthesis was detectable, newly synthesized viral polypeptides were incorporated into intracellular viral particles. Radioactive viral polypeptides appeared without a longer lag period in extracellular viruses from 6 hours p.i. onwards.
\end{abstract}

\section{Introduction}

Rotaviruses are a major cause of acute viral diarrhoea in a number of mammalian and avian species $(9,25)$. Several serotypes have been identified among rotaviruses from children $(2,36)$, calves $(5,16,27,30,33$, 35), foals (13), piglets (3), mice (12) and avian species (26). In calves about 90 per cent of rotavirus isolates belong to one serotype represented by 
bovine rotavirus (BRV) UK $(33,35)$. Two other serotypes of BRV have been described $(5,16,27,30,33,35)$. Prototype 1 BRV UK has been well characterized $(6,21,23,24,28,34)$, but detailed information about other serotypes of $B R V$ is scarce (31). In this report we give a biochemical description of the extracellular viral particles of BRV V 1005, which belongs to a second serotype of BRV, and its replication cycle in MA-104 cells.

\section{Materials and Methods}

\section{Viruses}

BRV UK, BRV NCDV, BRV V 1005 and simian rotavirus SA-11 were obtained from Prof. Bachmann (Institute of Medical Microbiology, Infectious and Epidemic Diseases, Veterinary Faculty, University of Munich, Federal Republic Germany). BRV V 1005 was isolated in his laboratory (1).

\section{Tissue Culture}

MA-104 cells were grown in $840 \mathrm{~cm}^{2}$ disposable glass roller bottles (Flow laboratories) in minimal essential medium containing 10 per cent foetal bovine serum and maintained after inoculation in medium 199 containing 10 per cent tryptose phosphate and $10 \mu \mathrm{g} / \mathrm{ml}$ porcine pancreatic trypsin (Flow laboratories cat. No. 16-893). BRV V 1005 was treated with $20 \mu \mathrm{g} / \mathrm{ml}$ of trypsin at $37^{\circ} \mathrm{C}$ for 30 minutes before inoculation. Cells were inoculated at a multiplicity of infection of $4 \mathrm{TCID}_{50}$ per cell. Infectivity titrations were done according to BACHMANN and Hess (1).

\section{Extracellular Rotavins Purification and Electron Microscopy}

Extracellular rotavirus particles were recovered from the cell-free culture supernatant of infected cells by high-speed centrifugation $\left(90,000 \times g, 2\right.$ hours, $\left.4^{\circ} \mathrm{C}\right)$ through a 20 per cent sucrose cushion. They were further purified by $\mathrm{CsCl}$ equilibrium centrifugation (SB405 rotor, International, $180,000 \times g, 18$ hours, initial density $\rho=1388 \mathrm{~g} / \mathrm{ml}$ ). The viral particles banding at the different density positions were recovered with a pasteur pipette, diluted with 0.9 per cent $\mathrm{NaCl}$ containing $10 \mathrm{~mm} \mathrm{CaCl}_{2}$ and pelleted by a further high-speed centrifugation $\left(130,000 \times g, 1\right.$ hour, $\left.4^{\circ} \mathrm{C}\right)$. Alternatively, viruses were pelleted after dilution with 0.9 per cent $\mathrm{NaCl}$ containing $10 \mathrm{~mm}$ EDTA. The viral particles were deposited on copper grids coated with a formvar film and carbon. They were negatively stained with a 2 per cent solution of phosphotungstic acid, pH 7.0. Particles were viewed with a Philips EM 300 electron microscope at $80 \mathrm{kV}$ accelerating voltage.

\section{Radioactive Labelling and Isolation of Intracellular Viral Particles}

The cells were labelled at $1-5,5-9,9-13$ and $13-17$ hours post infection (p.i.) with ${ }^{35} \mathrm{~S}$ methionine $(7 \mu \mathrm{Ci} / \mathrm{ml},>800 \mathrm{Ci} / \mathrm{mmol}$, New England Nuclear $)$ in methionine-free MEM containing $5 \mu \mathrm{g} / \mathrm{ml}$ trypsin. Alternatively, the cells were labelled at the same time intervals with ${ }^{3} \mathrm{H}$-uridine $(7 \mu \mathrm{Ci} / \mathrm{ml}, 80 \mathrm{Ci} / \mathrm{mmol}$, Amersham). Immediately after the labelling period, the cells of one roller bottle were scraped off, washed in ice-cold PBS and resuspended in $50 \mathrm{~mm}$ Tris- $\mathrm{HCl}$, pH 7.5 , containing $150 \mathrm{~mm} \mathrm{NaCl}, 10 \mathrm{mM} \mathrm{CaCl}_{2}, 5 \mu \mathrm{g} / \mathrm{ml}$ soybean trypsin inhibitor (Sigma) and 0.5 per cent of the nonionie detergent Nonidet$\mathrm{P} / 40$. The cellular extract was fractionated by differential centrifugation. Low-speed centrifugation $\left(800 \times g, 5\right.$ minutes, $\left.+4^{\circ} \mathrm{C}\right)$ was followed by medium-speed centrifugation $\left(10,000 \times g, 30\right.$ minutes, $\left.+4^{\circ} \mathrm{C}\right)$ and finally by high-speed centrifugation (130,000 $\times g$, 1 hour, $\left.+4^{\circ} \mathrm{C}\right)$. The high-speed pellet was checked by electron microscopy after negative 
staining. 90 per cent of the material consisted of rotaviral particles. Some small membrane-derived debris was also found in this fraction.

For the comparison of intracellular viral proteins of different rotavirus strains, the infection medium was replaced at 12 hours p. i. with $20 \mathrm{ml}$ methionine-free MEM to which $5 \mu \mathrm{Ci} / \mathrm{ml}$ of ${ }^{35} \mathrm{~S}$-methionine (Amersham Ltd.) was added. After one hour labelling, cells were scraped from the roller surface with a rubber policeman. The cells were washed in phosphate buffered saline and lysed in the gel electrophoresis sample buffer (20).

\section{Gel Electrophoresis}

Protein electrophoresis was carried out in slab gels by Laemmli's method (20) using 13 per cent running and 3 per cent stacking gels. Molecular weights were calibrated using a mixture of ${ }^{14} \mathrm{C}$-methylated polypeptides (Amersham), gels were fluorographed with Englightning (New England Nuclear), dried and exposed on X-ray films (Y AR-5, Kodak).

\section{Hyperimmunization of Mice and Guinea Pigs}

Purified viral particles [approximately $50 \mu \mathrm{g}$ proteins as determined by the method of BRADFORD (4) for each injection] were homogenized in Freund's complete adjuvant (first injection), in Freund's ineomplete adjuvant (second injection), and in phosphate buffered saline (third injection). The viruses were administered intraperitoneally into mice and intramuscularly into guinea pigs. Animals were previously shown to be free of neutralizing antibodies to BRV UK, V 1005 and simian rotavirus SA-11. Sera were analysed 20 days after the last injection for neutralizing aetivity against 100 TCID $_{50}$ of BRV UK, BRV V 1005 and simian rotavirus SA-11 with the immunoperoxidase microtiter neutralization test of GERNA et al. (11). NT-titers are expressed as the reciprocal of the serum dilution reducing the number of infected cells by 90 per cent.

\section{Column Chromatography}

The cells were labelled with ${ }^{3} \mathrm{H}$-uridine in the presence of $2 \mu \mathrm{g} / \mathrm{ml}$ actinomycin D (Serva). Cells were lysed for 1 hour at $37^{\circ} \mathrm{C}$ in $1 \mathrm{ml}$ TNE-buffer $(50 \mathrm{~mm}$ Tris-HCl, $\mathrm{pH} 6.9$; $1 \mathrm{~mm}$ EDTA, $100 \mathrm{~mm} \mathrm{NaCl}$ ) containing 0.8 per cent SDS (Sigma) and $500 \mu \mathrm{g} / \mathrm{ml}$ proteinase $\mathrm{K}$ (Merck).

After three phenol extractions the RNA was precipitated with ethanol (overnight, $-20^{\circ} \mathrm{C}$ ). Cellulose column chromatography was performed as described by FrankLIN (10). Each $1 \mathrm{ml}$ fraction was counted in $10 \mathrm{ml}$ Aquasol (NEN) in a liquid scintillation counter (Mark III, Searle).

\section{Results}

\section{Neutralization Tesl}

Neutralization tests with hyperimmune guinea pig and mouse sera showed that bovine rotavirus V 1005 was serologically distinct from bovine rotavirus UK, a prototype bovine rotavirus strain (Table 1). More than twenty times the limiting concentration of antisera which neutralized 100 TCID $_{50}$ of BRV UK failed to neutralize 100 TCID $_{50}$ of BRV V 1005 and more than 20 antibody units of sera to BRV V 1005 failed to neutralize 100 TCID $_{50}$ of BRV UK. BRV V 1005 is serologically as different from prototype BRV UK as is for example simian rotavirus SA-11. No significant serological interrelationship was detected between bovine rotavirus V 1005 and human 
Table 1. Serological differences between BRV UK and V1005

\begin{tabular}{|c|c|c|c|c|c|}
\hline \multirow{2}{*}{$\begin{array}{l}\text { Antiserum } \\
\text { to } \\
\text { rotavirus }\end{array}$} & \multirow[b]{2}{*}{ Animals $^{a}$} & \multicolumn{3}{|c|}{$\begin{array}{l}\text { Neutralizing antibody titerb } \\
\text { to rotavirus }\end{array}$} & \multirow{2}{*}{$\begin{array}{l}\text { Homologous/ } \\
\text { Heterologous } \\
\text { titer ratio }\end{array}$} \\
\hline & & UK & V 1005 & SA-11 & \\
\hline UK & Guinea pigs & $>12,800$ & 200 & 100 & $>64$ \\
\hline V 1005 & Guinea pigs & $<100$ & 6,400 & $<100$ & $>64$ \\
\hline SA-11 & Guinea pigs & 100 & $<100$ & $>12,800$ & $>128$ \\
\hline Preimmune & Guinea pigs & $<100$ & $<100$ & $<100$ & \\
\hline UK & Mice & $>12,800$ & $<100$ & $<100$ & $>128$ \\
\hline V 1005 & Mice & 100 & 3,200 & 100 & 32 \\
\hline SA-11 & Mice & $<100$ & $<100$ & 3,200 & $>32$ \\
\hline Preimmune & Mice & $<100$ & $<100$ & $<100$ & \\
\hline
\end{tabular}

a Mean of two animals

b Reciprocal of highest serum dilution inhibiting the replication of $10^{2} \mathrm{TCID}_{50}$ of indicated rotavirus in the neutralization test of GERNA et al. (II). Homologous titer in italics

rotavirus (HRV) Wa (serotype 1), HRV S-2 (serotype 2), simian rotavirus SA-11 (serotype 3) and IRV Hochi (serotype 4) (data not shown).

\section{Four Particle Types of Extracellular Rotavirus}

Extracellular BRV V 1005 grown in MA-104 cells was analyzed by CsCl density gradient centrifugation. Centrifugation resulted in the formation of four bands at buoyant densities of $1.31,1.315,1.36$ and $1.38 \mathrm{~g} / \mathrm{ml}$. By electron microscopy the band at $1.31 \mathrm{~g} / \mathrm{ml}$ was found to contain inner shell empty capsids of $55 \mathrm{~nm}$ diameter (Fig. $1 \mathrm{a}$ ). The band at $1.315 \mathrm{~g} / \mathrm{ml}$ showed larger $(65 \mathrm{~nm}$ ) and less organized empty capsids (Fig. $1 \mathrm{~b}$ ). The band at $1.36 \mathrm{~g} / \mathrm{ml}$ contained $65 \mathrm{~nm}$ virions (Fig. $1 \mathrm{c}$ ) and the band at $1.38 \mathrm{~g} / \mathrm{ml}$ gave $55 \mathrm{~nm}$ inner shell particles (Fig. $1 \mathrm{~d}$ ). In a typical experiment 90 per cent of the infectivity applied to the gradient was associated with $65 \mathrm{~nm}$ virions; inner shell particles showed much lower infectivities and empty capsids were essentially non-infectious (e.g. $10^{7.5} \mathrm{TCID}_{50}$ at $\rho=1.36 \mathrm{~g} / \mathrm{ml}$ versus $10^{5} \mathrm{TCID}_{50}$ at $\rho=1.38 \mathrm{~g} / \mathrm{ml}$ and $10^{2} \mathrm{TCID}_{50}$ at $\rho=1.31 \mathrm{~g} / \mathrm{ml}$ ).

\section{Polypeptide Composition of Extracellular Rotavirus}

The four particle types separated by $\mathrm{CsCl}$ density gradients were analysed by SDS-polyacrylamide gel electrophoresis (Fig. 2). Virions are composed of 6 polypeptides: four major polypeptides of molecular weight $83,000,60,000,43,000$ and 36,000 , one minor polypeptide of molecular weight 105,000 and a very weakly labelled protein of molecular weight 28,000 (Fig. 2, lane c). In comparison with virions, inner shell particles lack the polypeptides of molecular weight $60,000,36,000$ and 28,000 (Fig. 2, lane $\mathrm{d})$. The two types of empty capsids contain two polypeptides of molecular weight 75,000 and 55,000 (Fig. 2, lanes a, b) which are not found 

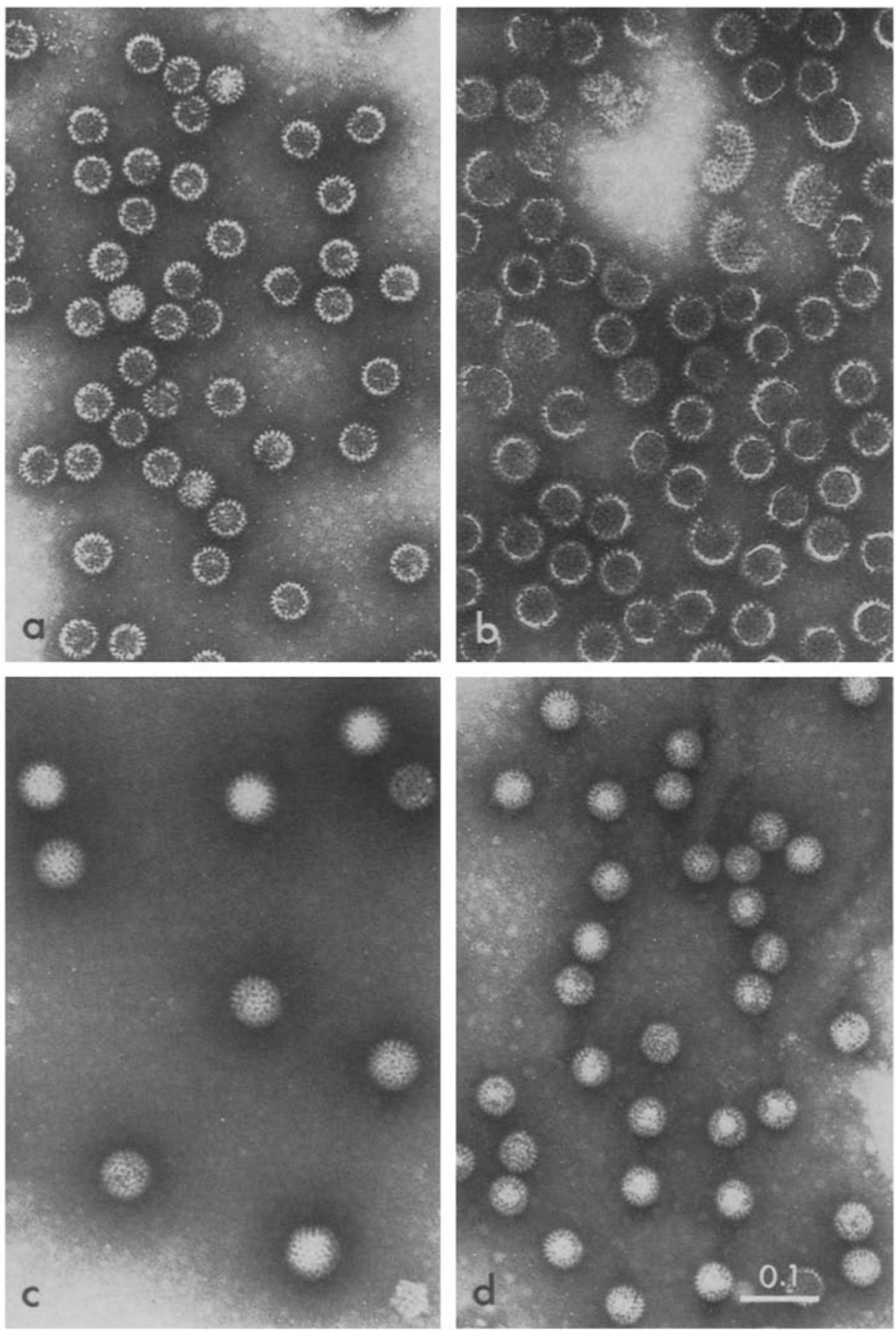

Fig. 1. Electron micrographs of extracellular bovine rotavirus V 1005 purified by CsCl density gradient centrifugation and negatively stained with 2 per cent phosphotungstic acid. $a$ small empty capsids; $b$ large empty capsids; $c$ virions and $d$ inner shell particles. 


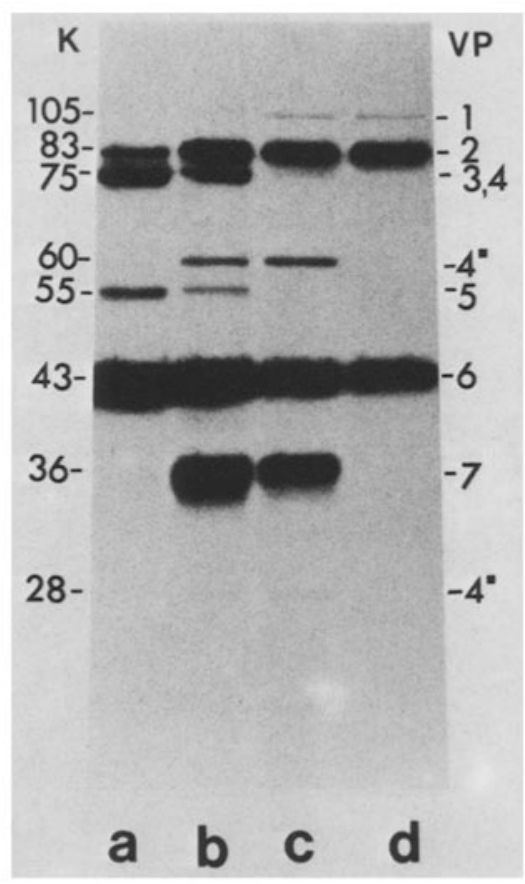

Fig. 2. SDS-polyacrylamide gel electrophoresis of [ ${ }^{3 \check{5} \mathrm{~S}]}$-methionine-labelled structural polypeptides of $a$ small empty capsids; $b$ large empty capsids; $c$ virions and $d$ inner shell particles. Apparent molecular weights in thousands are indicated on the left-hand side, the nomenclature system of (23) for bovine rotavirus polypeptides is indicated on the righthand side. Trypsin cleavage products of VP 4 are indicated by a dot

in virions. Otherwise they show the polypeptide composition of virions (Fig. 2, lanes B, c) or inner shell particles (Fig. 2, lanes a, d). Treatment of purified virions of BRV 1005 with EDTA removed the viral polypeptides of molecular weight 60,000 and 36,000 (Fig. 3), transforming the virions into inner shell particles (see also 7,23 ).

\section{Viral Protein Synthesis in Infected Cells}

BRV V 1005 induced the synthesis in infected MA-104 cells of polypeptides with molecular weights [minor polypeptides in parenthesis, VF nomenclature according to (23)] 105,000 (VP 1), 83,000 (VP 2), $(80,000)$ (VP 3), 75,000 (VP 4), (55,000) (VP 5), 43,000 (VP 6), 36,000 (VP 7), 35,000 (VP 8), $(34,000)$ (VP 9), 28,000 (VP 10), (20,000) (VP 11) (Fig. 4, lane b; Fig. 5 B, lanes d and e) which were not found in uninfected cells (Fig. 5 b, lane a). Intracellular polypeptides induced by BRV V 1005 were compared to those induced by BRV UK, BRV NCDV and simian rotavirus SA-11 (Fig. 4, lanes a to d). Slight molecular weight differences were observed for polypeptides with molecular weights 34,000 to 36,000 . VP 11 was consistently barely detectable in V 1005 infected cells. 


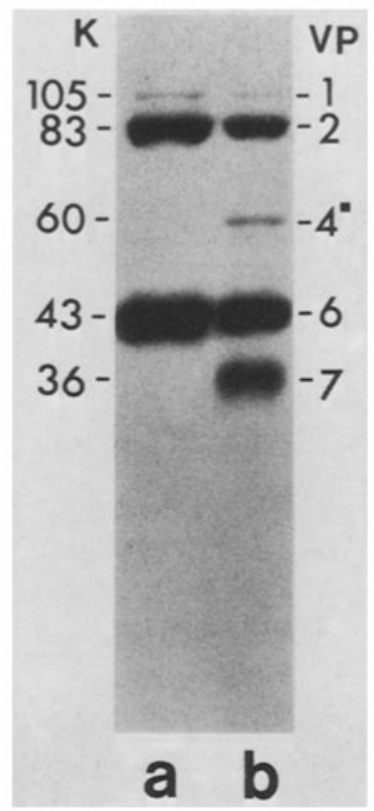

Fig. 3. SDS-polyacrylamide gel electrophoresis of [35 S]-methionine labelled virions after sedimentation in the presence of $10 \mathrm{mM}$ EDTA $(a)$ or $10 \mathrm{mM} \mathrm{CaCl}_{2}(b)$

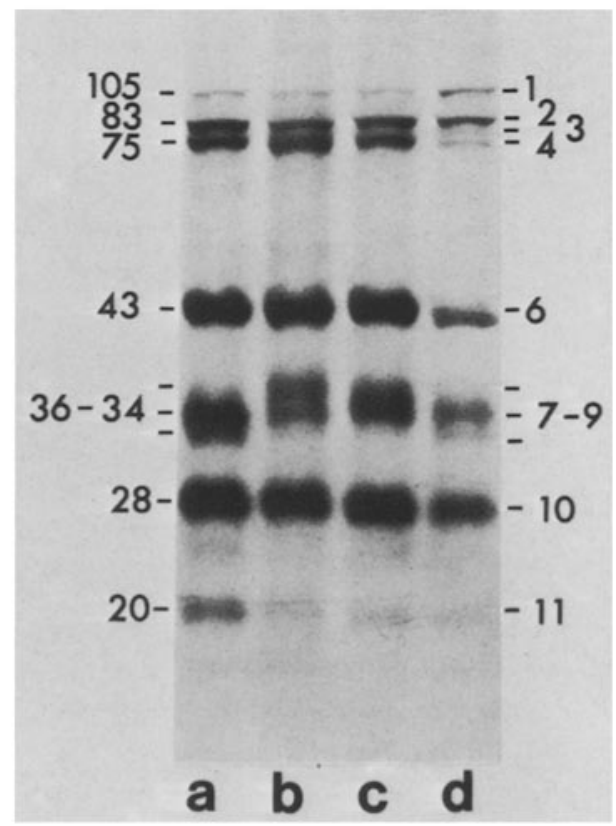

Fig. 4. Rotavirus polypeptide synthesis in MA-104 cells induced by BRV NCDV (a), BRV V 1005 (b), BRV UK (c) and simian rotavirus SA-11 (d). Cells were labelled with [ $\left.{ }^{35} \mathrm{~S}\right]-$ methionine between 12 and 13 hours post-infection. Apparent molecular weights in thousands are indicated on the left-hand side, and the nomenclature system of McCrAE and Fatlkner-VAlte (23) for bovine rotavirus polypeptides on the right-hand side 

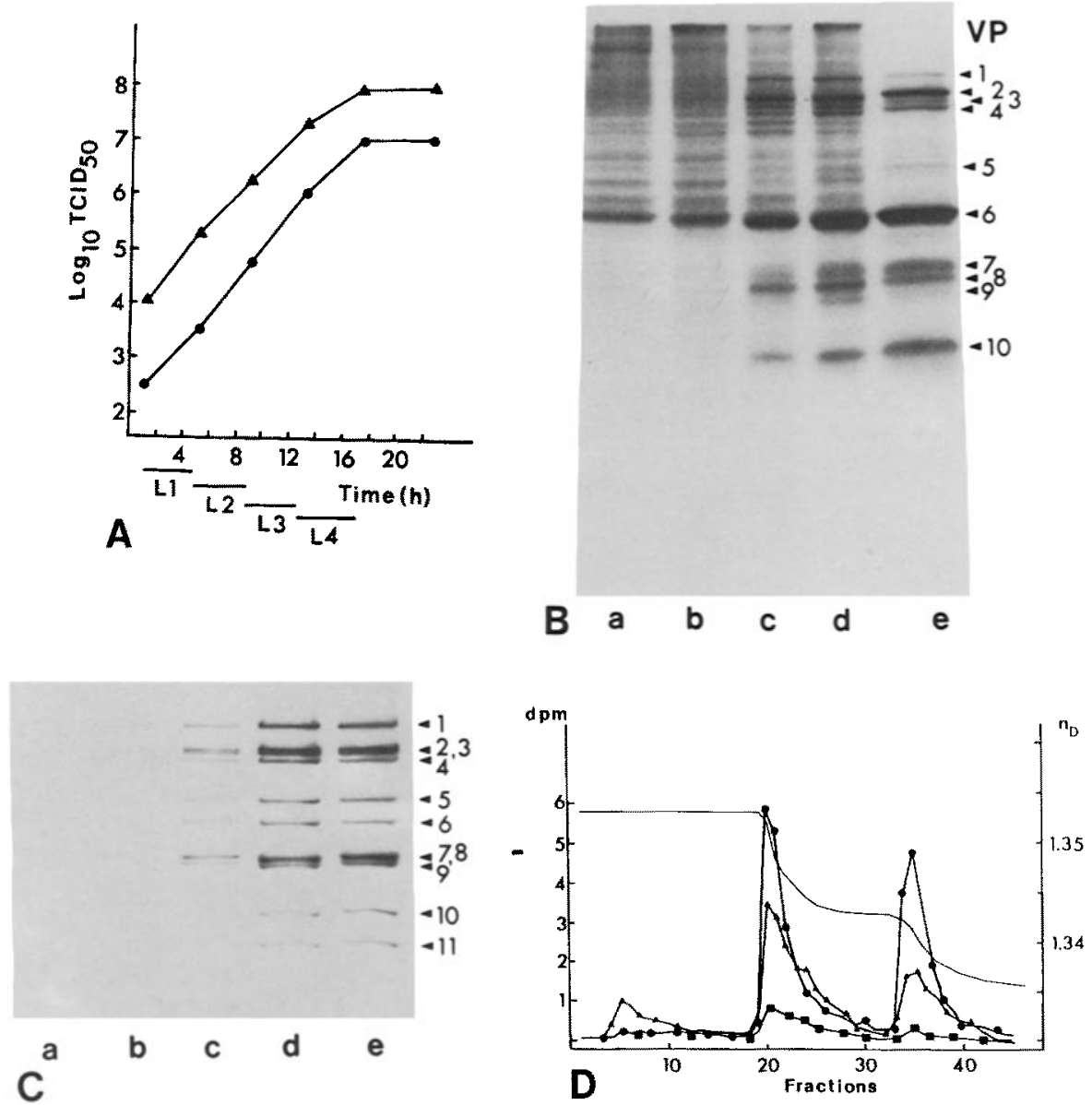

Fig. 5. Analysis of the replication eycle of bovine rotavirus 1005 on MA-104 cells. $A$ Growth curve or intracellular (A) and extracellular ( virus. $B$ Polyacrylamide gel analysis of the kinetics of intracellular viral polypeptide synthesis. $a$ uninfected cells; $b-e$ infected cells labelled at the time periods $L 1$ to $L 4$ indicated below the growth curve $(A)$. Viral polypeptides (VP) are numbered according to (23). C Polyacrylamide gel analysis of the kinetics of intracellular viral double-stranded RNA synthesis. $a$ uninfected cells; $b-e$ infected cells labelled at the time period $L I$ to $L 4$ indicated below the growth curve $(A) . D$ CF-11 cellulose column chromatography of intracellular RNA (dpm in thousands) from uninfected MA-104 cells ( $\mathbf{\square}$ ) and cells labelled at 5-9 hours p.i. (A) and 9-13 hours p.i. with ${ }^{3} \mathrm{H}$-uridime in the presence of actinomycin $\mathrm{D}$. The thin line indicates the refraction index $n_{D}$ of the elution buffer

\section{Time Course of Rotavirus V1005 Replication in MA-104 Cells}

When MA-104 cells were infected with bovine rotavirus V 1005 at a multiplicity of 4 TCID $_{50}$ /cell, infectious progeny virus appeared in the supernatant 5 hours p.i. and increased exponentially for up to 17 hours p.i. Before cell detachment, higher intracellular than extracellular titers of infectious 
virus were found (Fig. 5, A). With cell detachment at 30 hours p.i. the majority of intracellular virus was released into the medium.

The time periods when labelling experiments were performed with ${ }^{30} \mathrm{~S}$ methionine or ${ }^{3} \mathrm{H}$-uridine to correlate data on nucleic acid and protein synthesis in bovine rotavirus-infected cells with viral particle synthesis, are shown as L 1 to L 4 in Fig. 5, A.

In the first labelling period (L 1: $1-5$ hours p.i.) intracellular polypeptide synthesis was indistinguishable from uninfected cells (Fig. $5 \mathrm{~B}$, lanes a and b). In the second and third labelling period (L 2: 5-9, L 3: 9-13 hours p.i.) viral polypeptide synthesis was evident on a background of cellular protein synthesis (Fig. 5 B, lanes $\mathrm{c}$ and d). With the onset of cytopathic effects (13 hours p.i.) exclusively viral polypeptides were synthesized (L 4 period: 13-17 hours p.i.) (Fig. 5 B, lane e). Traces of double-stranded RNA were detected in the first labelling period (Fig. $5 \mathrm{C}$, lane b). Double-stranded RNA synthesis was clearly evident in the $\mathrm{L} 2$ period (Fig. $5 \mathrm{C}$, lane c), it increased within the $\mathrm{L} 3$ labelling period to remain stationary thereafter (Fig. $5 \mathrm{C}$, lanes $d$ and e).

Fig. $5 \mathrm{D}$ shows total intracellular RNA labelled with ${ }^{3} \mathrm{H}$-uridine in the presence of actinomycin $\mathrm{D}$, which was separated into single-stranded and double-stranded RNA on a CF-Il cellulose column. Actinomycin D treatment suppressed host RNA synthesis to background levels. Single-stranded RNA (fractions 20-25) and double-stranded RNA (fractions 33-38) were detected in the second labelling period and increased further in the third labelling period. Fractions 20-25 were susceptible to RNase A digestion

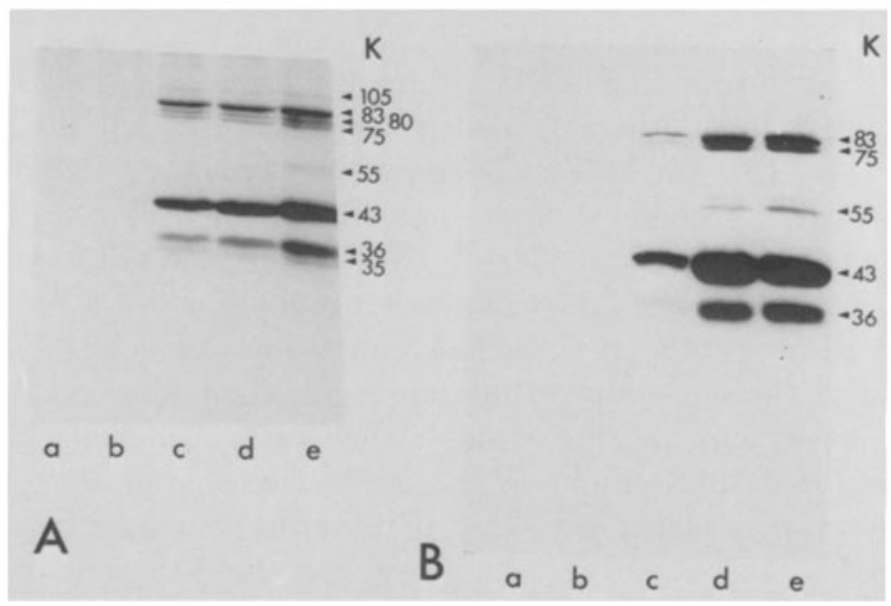

Fig. 6. Polyacrylamide gel analysis of the viral polypeptides found in intracellular $(A)$ and extracellular $(B)$ viral particles in the labelling periods L $1-\mathrm{L} 4(b-t)$. a uninfeeted cells. The apparent molecular weight of the viral polypeptides are indicated in thousands $(K)$ 
$\left(0.1 \mu \mathrm{g} / \mathrm{ml}, 0.1 \mathrm{M} \mathrm{NaCl}, 37^{\circ} \mathrm{C}, 1\right.$ hour$)$, whereas fractions $33-38$ were resistant (data not shown).

Neither extracellular nor intracellular viral particles were synthesized in the first labelling period (Fig. $6 \mathrm{~A}, \mathrm{~B}$, lane b respectively). From the second labelling period onwards newly synthesized intracellular and extracellular particles were detected (Fig. $6 \mathrm{~A}, \mathrm{~B}$, lane e respectively) to reach maximal levels in the fourth labelling period.

\section{Discussion}

According to the criteria developed for serotype distinction of ECHOviruses (8), rhinoviruses (18) and rotaviruses (36), bovine rotavirus $\mathrm{V} 1005$ can be attributed to a second $\mathrm{BRV}$ serotype. It is serologically different from prototype BRV UK [serotype 6 according to (14)] and four human rotavirus serotypes [serotype 1-4 according to (14)]. Actually we do not know whether rotavirus $V 1005$ resembles serotype 5 (porcine rotavirus OSU, equine rotavirus $\mathrm{H}-1$ ) or avian serotype 7 rotavirus defined by Hoshino et al. (14) or whether it represents still another rotavirus serotype. In view of serologically distinct and still not classified rabbit (32) and mouse (12) rotaviruses, the number of rotavirus serotypes in mammalian species may be reasonably greater than the 6 serotypes defined by Hoshino (14).

The outer shell proteins are the most relevant for the serological distinction of BRV $(17,19,22,29,31)$. Of the three polypeptides identified in the outer shell of BRV 1005 that of molecular weight 36,000 and corresponding to VP $7(23)$ is the major protein, followed by a polypeptide of molecular weight 60,000 . The polypeptide of 28,000 molecular weight is only a minor component. A similar polypeptide composition was reported for the outer shell of BRV UK (34) and BRV NCDV (22). Some authors have described a further outer shell protein of BRV with molecular weight similar to that of $\operatorname{VP} 7(6,19,21)$, whilst others have attributed this protein to the inner shell (23). Novo et al. (28) and McCrae and FAuLKner-VALLe (23) described a VP 4 protein as a prominent outer shell constituent. We have found this polypeptide only in empty capsids of BRV V 1005, and not in virions. The outer shell polypeptide of molecular weight 60,000 is not a primary gene product of BRV V 1005, because no homologous viral protein is found intracellularly. Therefore it probably represents the major tryptic cleavage product of VP 4, with the minor outer shell protein of molecular weight 28,000 found in V 1005 virions as the minor cleavage product $(6)$.

The major tryptic cleavage product of rotavirus hemogglutinin was in the past referred to as VP5 $(6,21,22)$. However, the fifth gene of BRV UK codes for a VP 5 polypeptide which is only weakly labelled in cells (24). MCCRAE and MCCORQUODALE (24) described this VP 5 as a non-structural polypeptide because it was not found in inner shell particles and virions. 
Actually we detected in empty capsids, but not in inner shell particles or virions a polypeptide with the molecular weight of VP $5(55,000$ in our gel system). Further work must define the identity of this empty capsid-specific polypeptide.

The following conclusions can be drawn from the biochemical analysis of the replication cycle of $\mathrm{V} 1005$ rotavirus in MA-104 cells. First, we found that viral polypeptide synthesis was correlated in time with viral doublestranded RNA synthesis. Second, a distinction of early and late synthesis products was not evident for intracellular V 1005 polypeptide synthesis, genomic RNA synthesis and intracellular and extracellular viral particles. Third, as soon as viral polypeptide synthesis was differentiable from the background of host protein synthesis, newly synthesized viral polypeptides were incorporated into intracellular particles. Fourth, newly synthesized viral polypeptides appeared without a longer lag period in extracellular viral particles even before any cytopathic effects were evident in the cell monolayer.

With the possible exception of the major outer shell protein VP 7, most intracellular viral polypeptides of BRV V 1005 were similar in molecular weight to those of BRV UK and NCDV. This contrasts to the extensive variations in molecular weights reported for intracellular viral polypeptides of rotaviruses from different species (34). However, the apparent molecular weight alone may not be a meaningful criterion to assess the relationship between rotaviral polypeptides of different rotavirus strains.

The similarity and variation in rotaviral structural polypeptides between prototype BRV UK and the second BRV serotype V 1005 defined in this paper is presently being investigated in our laboratory using biochemical and immunological methods.

\section{Acknowledgement}

We wish to thank the late Prof. P. Bachmann for the gift of BRV V 1005 and his encouragement of our work, Miss M. de Tiani for analysis of viral RNA on CF-11 columns, Dr. I. Horman for correcting the English text, Mrs. M. Weber and Mr. B. Pugin for photographic work and Mrs. C. Isom for careful typing of the manuscript.

\section{References}

1. Bachmann PA, Hess RG (1981) Routine isolation and cultivation of bovine rotaviruses in cell culture. Am J Vet Res 42: 2149-2150

2. BeARDS GM, FLEweTt TH (1984) Serological characterization of human rotaviruses propagated in cell culture. Arch Virol 80: 231-237

3. BoHL EH, THEIL KW, SAIF LJ (1984) Isolation and serotyping of porcine rotaviruses and antigenic comparison with other rotaviruses. J Clin Microbiol 19: 105-111

4. BRADFORD M (1976) A rapid and sensitive method for the quantitation of microgram quantities of protein utilizing the principle of protein dye binding. Anal Biochem 72 : $248-254$ 
5. BrIDger JC, Brown JF (1984) Antigenic and pathogenic relationships of three bovine rotaviruses and a porcine rotavirus. $J$ Gen Virol 65: 1151-1158

6. Clark SM, Roth JR, Crark ML, Barnett BB, Spendlove RS (1981) Trypsin enhancement of rotavirus infectivity: mechanism of enhancement. J Virol 39: 816-822

7. Cohen J, Laporte J, Charpilienne A, Scherrer R (1979) Activation of RNA polymerase by calcium chelation. Arch Virol 60: 177-186

8. Committee on the ECHO Viruses (1955) Enteric cytopathogenic human orphan (ECHO) viruses. Seience 122: 1187-1188

9. FLewetT TH, WoOde GN (1978) The rotaviruses. Arch Virol 57: 1-23

10. FrankLIN RM (1966) Purification and properties of the replicative intermediates of the RNA bacteriophage R17. Proc Natl Acad Sci USA 55: 1502-1511

11. Gerna G, Battaglia M, Mrlenest G, Passavani N, Percivalle E, Cattaneo E (1984) Serotyping of cell-culture-adapted subgroup 2 human rotavirus strains by neutralization. Infect Immun 43: 722-729

12. GREENBERG HB, Vo PT, Jones $R$ (1986) Cultivation and characterization of three strains of murine rotavirus. J Virol 57: $585-590$

13. Hosmino $Y$, Wyatt RG, Greenberg HB, Kalica AR, Flores J, Kapikian AZ (1983) Isolation, propagation and characterization of a second equine rotavirus serotype. Infect Immun 41: 1031-1037

14. Hosmino Y, Wyatt RG, Greenberg HB, Flores J, Kapikian AZ (1984) Serotypic similarity and diversity of rotaviruses of mammalian and avian origin as studied by plaque-reduction neutralization. J Infect Dis 149: 694-702

15. Hoshino Y, Sereno MM, Midthun K, Flores J, Kaplkian AZ, Chanock RM (1985) Independent segregation of two antigenic specificities (VP 3 and VP 7) involved in neutralization of rotavirus infectivity. Proc Natl Acad Sci USA 82: 8701-8704

16. Ihara T, Samejuma T, KuWahara H, Tayima M (1983) Isolation of new serotypes of bovine rotavirus. Arch Virol 78:145-150

17. Kalioa AR, Grementerg HB, Wyat' RG, Flores J, Sereno MM, Kapikian AZ, CHANOCK RM (1981) Genes of human (strain Wa) and bovine (strain UK) rotaviruses that code for neutralization and subgroup antigens. Virology 112: 385-390

18. Kaptkian AZ, Conant RM, Hamparian VV, Chanock RM, Chapple PJ, Diok EC, Fenters JD, Gwaltney JR, JM, Hamre D, Holper JC, Jordan Jr, WS, Lennette EH, Mernick JL, Mogabgab WJ, Mufson MA, Phillips CA, Schieble JH, TyrReLI DAJ (1967) Rhinoviruses: a numbering system. Nature 213: 761-763

19. KILLEN HM, DTMmock NJ (1982) Identification of a neutralization-specific antigen of calf rotavirus. J Gen Virol 62: 297-311

20. LAEMmLI UK (1970) Cleavage of structural proteins during the assembly of the head of bacteriophage T 4. Nature 227: 680-685

21. Matsuno S, Mrkoxama A (1979) Polypeptides of bovine rotavirus. J Gen Virol 43 : 309-316

22. Matsuno S, Inouye S (1983) Purification of an outer capsid glycoprotein of neonatal calf diarrhea virus and preparation of its antisera. Infect Immun 39: 155-158

23. MoCrae MA, Faulkner-Valde GP (1981) Molecular biology of rotavirus. I. Characterization of basic growth parameters and pattern of macro-molecular synthesis. $J$ Virol 39: 490-496

24. MoCrat MA, MoCorquodale JG (1982) The molecular biology of rotaviruses. II. Identification of the protein-cooling assignments of calf rotavirus genome RNA species. Virology 117: 435-443

25. MCNuLTY MS (1978) Rotaviruses. J Gen Virol 40: 1-18

26. MoNulty MS, Allan GM, Todd D, MoFerran JB, MoKillop ER, Collins DS, MCCraCken RM (1980) Isolation of rotaviruses from turkeys and chickens: demon- 
stration of distinct serotypes and RNA electropherotypes. Avian Pathol 9: 363375

27. Murakami $Y$, Nishioka N, Hashiguchi $Y$, Kuniyashu $C$ (1983) Serotypes of bovine rotaviruses distinguished by serum neutralization. Infect Immun 40: 851-855

28. Novo E, Esparza $\mathfrak{J}$ (1981) Composition and topography of structural polypeptides of bovine rotavirus. J Gen Virol 56: 325-335

29. Ofwxt PA, Blavat G (1986) Identification of the two rotavirus genes determining neutralization specificities. I Virol 57: 376-378

30. OJeh CK, SNodgrass DR, Herring AJ (1984) Evidence for serotypic variation among bovine rotaviruses. Arch Virol 79: 161-171

31. Sabara M, Gilchrist JE, Hudson GR, Babruk LA (1985) Preliminary characterization of an epitope involved in neutralization and cell attachment that is located on the major bovine rotavirus glycoprotein. J Virol 53: 58-66

32. Sato K, Inaba Y, Miura Y, Tokuhisa S, Matumoto M (1982) Antigenic relationships between rotaviruses from different species as studied by neutralization and immunofluorescence. Arch Virol 73: 45-50

33. Snodgrass DR, OJeh CK, Campbell I, Herring AJ (1984) Bovine rotavirus serotypes and their significance for immunization. J Clin Microbiol 20:342-346

34. Thovless ME (1979) Rotavirus polypeptides. J Gen Virol 44: 187-197

35. Woode GN, Kelso NE, Sumpson TR, Gaul SK, Evans LE, Babruk L (1983) Antigenic relationship among some bovine rotaviruses: serum neutralization and crossprotection in gnotobiotic calves. J Clin Microbiol 118: 358-364

36. Wyatt RG, Greenberg HB, James WD, Pittmann AL, Kalica AR, Flores J, Chanock RM, KaptKian AZ (1982) Definition of human rotavirus serotypes by plaque reduction assay. Infect Immun 37: 110-115

Authors' address: Dr. H. Brüssow, Immunology Section, Nestlé Research Department, Nestec Ltd., Avenue Nestlé 55, CH-1800 Vevey, Switzerland.

Received June 13, 1986 